\title{
THE USE OF POWERPOINT AS THE INSTRUCTIONAL MEDIA IN TEACHING ENGLISH FOR YOUNG LEARNERS
}

\author{
Triana Dewi $^{1}$, Evie Kareviati ${ }^{2}$ \\ 1,2 IKIP Siliwangi \\ ${ }^{1}$ trianadewi@ student.ikipsiliwangi.ac.id, ${ }^{2}$ ekareviati@gmail.com
}

\begin{abstract}
This research is about the use of powerpoint as the instructional media in teaching english for young learners at the first semester of the sixth grade students of SDN Baros Mandiri 5. The objective of this research are to analyze the use of powerpoint as the instructional media in teaching english for young learners. Data is collected through observation and interview. The reseacher chose class VIB as sample which consisted of 30 students. The data is then analyzed using observation sheets. The observations is began at 08.30 - 09.40 for 2 x 35 minutes with the teaching material "Go Green Save the Earth". Based on the results of media observations in the learning process of children and interviews with teachers, the media used by teachers in class VI is good and effective. The media used is powerpoint which is powerpoint is very helpful for teachers to prepare teaching materials and can help attract students' interest and attention so students can learn well.
\end{abstract}

Keywords: PowerPoint, Young Learners, Instructional Media

\section{INTRODUCTION}

Teaching English to Young Learners is a course for all teachers of primary age students. It aims to provide teachers with the knowledge and skills needed to support young learners through the delivery of engaging and motivating lessons. Teaching for elementary school students is not the same as teaching adults because they have different characteristics and motivations. Young children learn differently from teenagers, and adults in the following fields. They respond to meaning even though they do not understand individual words; learn indirectly from their environment; explore from what they see and hear touch and interaction; show enthusiasm for learning and curiosity about the world around them; have individual attention needs and approval from the teacher; talk about themselves, and respond when their lives become the main topic in class; and has a limited attention span; unless the activity is really fun which does not quickly make them bored, lose interest after about 10 minutes (Harmer, 2003) cited in (Yuliani et al., 2019).

There are some common characteristics of the children in the group (a) they are competent users of mother tongue, (b) they can distinguish between facts and fiction, (c) they like to play and learn best when they enjoy themselves seriously and like think that what they do in real work, (d) they rely on spoken and physical words to convey and understand meaning, (f) they can work with others and learn from others, $(\mathrm{g})$ ) their own understanding come through the eyes, hands, ears, (h) they have very short attention. According to Crosse (2007) cited in Sehan (2018). We need to understand that children in playgroups or kindergartens carry their home culture including the language they acquire and use every day. In fact, in England, where English is the native language, children do not start learning English until they start in the early years or formal settings. 
There are many factors to ensure that teaching English to young learners will be effective, such as teaching materials, teaching styles, learning styles, selection of appropriate instructional media and many other factors. Media can be one of a component of active learning strategies such as group discussions or case studies. Media is a tool for the learning process both inside and outside the classroom, further explaining that the learning media is a component of learning resources or physical vehicles containing the instruction material in the student environment that can stimulate students to learn (Azhar, 2011) cited in (Ristyani et al., 2020). In this case, the media to be used is PowerPoint which basically uses technology. Technology has always been an important part of the learning and teaching environment. This is an important part of the teaching profession through which they can use it to facilitate student learning. Harmer (2007) and Gençter (2015) cited in Ahmadi (2018) emphasize that teachers must encourage students to find appropriate activities through the use of computer technology in order to succeed in language learning.

The use of media to enhance teaching and learning complements traditional approaches to learning. Effective instruction builds bridges between students' knowledge and the learning objectives of the course. Using media engages students, aids student retention of knowledge, motivates interest in the subject matter, and illustrates the relevance of many concepts. The use of media is very important when the teaching process is expected to achieve better results or high learning achievement. Adegbija and Fakomogbon (2012) cited in Sanjaya et al (2018) state that learning media are human and non-human devices, materials or methodologies used by teachers to overcome all learning problems, including noise factors. Learning media are key in effectively transferring knowledge to students.

Powerpoint is chosen by the teacher to be used as a learning medium. PowerPoint is very helpful for teachers to prepare teaching materials and can help attract students' interest and attention so students can learn well. According to Susskind (2005) cited in Agbevivi (2018) PowerPoint helps explain complex illustrations, helps maintain student interest and attention at presentations, and so far enhances student learning. Meanwhile, according to Yusri, et al (2017) cited in Mulyawati \& Ghani (2019) Microsoft Power Point is the right software to create visual presentations that can interpret various media, such as videos, animations, images, and sounds. In Microsoft Power Point There is a menu that allows users to create and develop learning media that is more interesting, more interactive, and more enjoyable.

\section{METHOD}

Observation and interview methods are used by observers. The use of observation has historically been closely related to qualitative methodological approaches to social research, and especially ethnography because it appears to embody the principle of naturalism: people observed in everyday settings without artificial structures asking them to take part in interviews or to fill out questionnaires (Coffey, 2006) cited in (Harding, 2018). Observation is the process of direct and systematic observation and recording of symptoms that we will examine. This observation becomes one of the data collection techniques if it is in accordance with the objective of the study, which is planned and recorded systematically. According to Ciesielska et al (2018) Observation is one of the most important research methods in social science and at the same time the most diverse. This term includes several types, techniques, and approaches, which may be difficult to compare in terms of implementation and anticipated results; the choice must be adjusted to the research. And this time the writer as an observer has observed the VIB class at SDN Baros Mandiri 5 to observe the use of media in children's learning. 
This observation was made for an English teacher who taught material about "Go Green Save the Earth". Where the contents of the material from "Go Green Save the earth " is (1) using products and goods that are environmentally friendly (there are eco-friendly or ozone friendly labels), (2) How to make savings in using fossil fuels (gasoline, diesel and kerosene), or by using bio fuels, better ride public vehicles and walk Aja Kalo places that we are not too far , (3) $\mathrm{CO}$ (carbon monoxide) and $\mathrm{Pb}$ (lead) that is filled with gasoline engines is very hazardous to health; $\mathrm{CO}$ can enter in the blood and join the haemoglobin so that it interferes with its main function as an oxygen binder, $\mathrm{Pb}$ harmful to health especially children and pregnant women because the content of heavy metals can poison brain cells in the fetus, (4) Refuse plastic bag! Because plastic is a compound that is hard to break down and is a source of methane $(\mathrm{CH} 4)$ that causes Global Warming! When you are shopping, try to bring your own bag from home!, (5) planting trees and making space green open, because leaves from trees can absorb $\mathrm{CO} 2$ emissions from combustion, (6) dispose of trash in place by first by type! Dry garbage = Nonorganic garbage, wet trash $=$ organic waste and waste reduction $=$ waste of burning residue from organic and non-organic waste. Better yet kalo we have a basket Takakura or composter organic waste on its own.

An interview is a conversation between two or more people between the interviewer and the resource person. In addition, this interview aim to make sure about the result of the observation and to get more data related to this research. According to Lodico (2010) cited in Latifah \& Rahmawati (2019), there are five types of interview, they are one to one, group interview, structured interview, semistructured interview, unstructured interview. The writer used one to one type interview. The writer interviewed the teacher to get information on how to use PowerPoint as a learning medium for VIB grade students at SDN Baros Mandiri 5.

\section{RESULTS AND DISCUSSION}

\section{Results}

\section{A. Result of Observation}

The observations made by the observer are as follows:

School Name : :SDN Baros Mandiri 5

School Address : Jl. Jend. Sudirman No.150, Baros the Middle of Cimahi, Cimahi, West Java.

Class : VIB

Observers : : Triana Dewi

\begin{tabular}{lc}
\hline \multicolumn{1}{c}{ Description } & Observation \\
\hline $\begin{array}{l}\text { Appropriateness of instructional media with } \\
\text { student's characteristics }\end{array}$ & $\sqrt{ }$ \\
\hline $\begin{array}{l}\text { Appropriateness of instructional media with the } \\
\text { instructional goal }\end{array}$ & $\sqrt{ }$ \\
\hline $\begin{array}{l}\text { Appropriateness of instructional media with the } \\
\text { material }\end{array}$ & $\sqrt{ }$ \\
\hline $\begin{array}{l}\text { Appropriateness of instructional media with the } \\
\text { activities }\end{array}$ & $\sqrt{ }$ \\
\hline $\begin{array}{l}\text { Appropriateness of instructional media with } \\
\text { learning condition }\end{array}$ & \multicolumn{2}{|}{} \\
\hline Practicality of instructional media & \\
\hline
\end{tabular}




\section{Discussion}

1. Observation Results

The observations is began at 08.30 - 09.40 for 2 x 35 minutes with the teaching material "Go Green Save the Earth". The activities carried out during the learning process are divided into 3 activities namely preliminary activities, core activities, and closing activities.

In the preliminary activities, the teacher greets the students and asks what kind of breakfast with English menu to use for the students in the class. After that the teacher absent students and continued with answering guesses related to "job", "place", "country", "person", "animal", "shape". The teacher repeats the material about "Go Green Save the Earth" and then gives a class scenario that there will be a division of groups according to the line that will play about the material using the "Ranking 1" method.

The teacher gives some pictures about "Go Green Save the Earth" in the powerpoint that is displayed with the projector. Students are then asked to discuss with the group to answer the exact expression in accordance with the material that has been taught. After finishing playing Rank 1, the teacher gives the learning objectives learned that day and provides information about the next meeting material which is about "money". Last is the closing activity with a little game of black and green pat.

2. Interview results

Observer interviewed an English teacher at SDN Baros Mandiri 5 named Siti Yuni Nurjanah, S.Pd. who came from Purwakarta was a graduate of IKIP Siliwangi, graduated in 2014. She taught at SDN Baros Mandiri 5 since September 2018 until now and taught in classes II, III, and VI. She has non-formal teaching experience at ASMA GATSU (English Course).

The media used during the learning process are the projectors and PowerPoint. The reason she choose the projector and PowerPoint as the media was because it was easy and could attract the attention of students and save energy in learning. The problems encountered when using these media are unstable electricity voltage and projector availability. The strategy taken to solve the problem is if the electricity fails and there is no projector is learning to use textbooks. The Discussion should be an interpretation of the results rather than a repetition of the Results. The Discussion should be an interpretation of the results rather than a repetition of the Results. The Discussion should be an interpretation of the results rather than a repetition of the Results. The Discussion should be an interpretation of the results rather than a repetition of the Results. The Discussion should be an interpretation of the results rather than a repetition of the Results.

\section{CONCLUSION}

Based on the results of observations media in the learning process of children and interviews with teachers, the media used by teachers in class VI is good and effective. The media used are projectors and powerpoints. The teacher uses the media because it is to attract students' attention and is easy to use during the learning process as well as saving energy by not writing much on the board. In the learning process the teacher can make students communicative with questions and answers, besides the teacher also provides games to make the atmosphere not boring. 


\section{ACKNOWLEDGMENTS}

Alhamdulillahirabbil'alamin, praise and thank you to Allah SWT. I would like to express my gratefulness who helped, guided, and supported in writing and finishing this article and praise God for the blessings given to authors so that I complete this article.

\section{REFERENCES}

Agbevivi, S. L. G. (2018). The Use of PowerPoint in Teaching and Learning English in the University of Education, Winneba. African Journal of Interdisciplinary Studies, 11, 74 86.

Ahmadi, M. R. (2018). The Use of Technology in English Language Learning: A Literature Review. International Journal of Research in English Education (IJREE), 3(2), 115-125.

Ciesielska, M., Wolanik Boström, K., \& Öhlander, M. (2018). Observation Methods. Qualitative Methodologies in Organization Studies, 1(12), 33-52.

Harding, J. (2018). Qualitative Data Analysis: From Start to Finish. SAGE Publications Limited.

Latifah, N., \& Rahmawati, I. N. (2019). Teaching And Learning Narrative Text Writing Through Story Mapping. English Education: Jurnal Tadris Bahasa Inggris, 12(1), 78-96.

Mulyawati, Y., \& Ghani, R. A. (2019). Comparison of IPS Learning Results Using Monopoly Media and Power Point Media. Jhss (Journal of Humanities and Social Studies), 3(2), 8689.

Ristyani, N. A., Nurhayati, \& Husnussalam, H. (2020). Improving Students' Interest By Using Picture Media at TK Nur Assalam. PROJECT (Professional Journal of English Education), 3(1), 1-4.

Sanjaya, I. B. M. A. ., Batan, G., \& Myartawan, I. P. N. . (2018). An Analysis of Instructional Media Used by the English Teacher in Relation to Students ' Learning Interest and Motivation in SMP Laboratorium. Jurnal Pendidikan Bahasa Inggris Undiksha, 5(2).

Sehan, Z. (2018). An Investigation on the Last Year EFL University Students' Ideas on Using Story in Teaching English to Young Learners. Journal of Language and Linguistic Studies, 14(1), 125-138.

Yuliani, M., Sintu, G. M. M., \& Yugafiati, R. (2019). The Copping Strategies in Reducing Anxiety While Teaching EYL. PROJECT (Professional Journal of English Education), 2(1), 7-13. 